\title{
THE EFFECT OF MOTIVATION ON ENGLISH LITERATURE READING TO MEDICAL STUDENTS' BLOCK EXAMINATION SCORE
}

\author{
Dinda Carissa ${ }^{1 *}$, Yunia Hastami², Eti Poncorini Pamungkasari ${ }^{2}$ \\ ${ }^{1}$ Fakultas Kedokteran, Universitas Sebelas Maret, Surakarta - INDONESIA \\ ${ }^{2}$ Unit Pendidikan Kedokteran, Fakultas Kedokteran, Universitas Sebelas Maret, Surakarta - INDONESIA
}

Submitted: 26 March 2020; Final Revision from Author: 09 July 2020; Accepted: 23 July 2020

\begin{abstract}
Background: The reading interest rate of Indonesian society is relatively low (approximately 0,001). Meanwhile, during their study, medical students have to read numerous English literatures. Previous research showed that reading activity can be improved by reading motivation. However, studies about Indonesian medical students reading motivation on English literature are still limited. This study aims to assess the effect of students' English literature reading motivation to the block exam average score.
\end{abstract}

Methods: This was a cross-sectional study conducted in January 2018. We used stratified random sampling, and we found 274 samples that fit with inclusion and exclusion criterias selected. The motivation was assessed using the English literature reading motivation scale, block exam test results were obtained through the academic database. Data were analyzed with multiple linier regression test.

Result: Students' English reading motivation increased the block exam average score of Medical Students. Every increase of one score of motivation significantly increase 0,10 score block exam average $(p<0,001)$. Furthermore, every increase of one year of study can significantly increase 3,53 of block exam average score $(p<0,001) ; R^{2}=18,3 \%$. English literature reading motivation of medical students UNS is in middle category.

Conclusion: English literature reading motivation increase the block exam average score of Medical Students in UNS.

Keywords: reading motivation, English literature, exam score, medical student

\section{ABSTRAK}

Latar belakang: Angka minat baca pada masyarakat Indonesia sangat rendah (sekitar 0,001). Sementara, mahasiswa kedokteran harus membaca literatur berbahasa Inggris. Penelitian sebelumnya menyatakan bahwa aktivitas membaca dapat ditingkatkan dengan motivasi membaca. Penelitian tentang motivasi membaca literatur berbahasa Inggris pada mahasiswa kedokteran di Indonesia masih sangat terbatas. Tujuan penelitian ini adalah untuk menganalisis pengaruh motivasi membaca literatur berbahasa Inggris terhadap nilai rata-rata ujian blok.

Metode: Penelitian yang dilaksanakan pada Januari 2018 ini merupakan penelitian analitik dengan pendekatan cross sectional. Terdapat 274 sampel yang memenuhi kriteria inklusi dan eksklusi yang dipilih dengan teknik sampling acak bertingkat. Motivasi membaca literatur berbahasa Inggris diukur menggunakan skala motivasi membaca literatur berbahasa Inggris. Data yang diperoleh diuji dengan uji regresi linear ganda.

*corresponding author, contact: dindacarissa28@gmail.com 
Hasil: Setiap peningkatan satu skor motivasi membaca literature berbahasa Inggris akan meningkatkan nilai rata-rata blok sebesar 0,10; setiap peningkatan satu tahun lama studi akan meningkatkan nilai rata-rata blok sebesar 3,53, signifikan secara statistik, $\mathrm{R}^{2}=18,3 \%$. Motivasi membaca literatur berbahasa Inggris mahasiswa Prodi Kedokteran FK UNS berada pada kategori sedang.

Kesimpulan: Terdapat pengaruh motivasi membaca literatur berbahasa Inggris terhadap nilai rata-rata ujian blok pada mahasiswa Prodi Kedokteran FK UNS.

Kata Kunci: motivasi membaca, literatur berbahasa Inggris, nilai ujian blok, mahasiswa kedokteran

\section{PRACTICE POINTS}

- Motivasi membaca literatur berbahasa Inggris merupakan salah satu faktor penentu keberhasilan pembelajaran pada prodi kedokteran.

- Dibutuhkan peran mahasiswa dan institusi kedokteran untuk meningkatkan motivasi intrinsik, ekstrinsik dan kemampuan membaca literatur berbahasa Inggris.

\section{PENDAHULUAN}

Hasil survei UNESCO menunjukkan bahwa angka minat baca di Indonesia (termasuk mahasiswa) hanya sebesar 0.001, yang berarti dari 1000 orang hanya 1 yang mempunyai minat baca. ${ }^{1}$ Rendahnya minat baca mahasiswa semakin memperburuk kenyataan bahwa selama kuliah, salah satu yang harus mahasiswa hadapi adalah membaca literatur. ${ }^{2}$ Hampir semua literatur termasuk jurnal serta guideline berbagai penyakit menggunakan bahasa Inggris. $80,1 \%$ penelitian dipublikasikan dalam bahasa Inggris. ${ }^{3}$ Peningkatan penggunaan bahasa Inggris sebagai bahasa global memiliki pengaruh besar dalam sistem pendidikan di seluruh dunia. Dalam hal ini, membaca teks berbahasa Inggris merupakan suatu tuntutan. ${ }^{4}$

Pada Prodi (Program Studi) Kedokteran FK UNS (Fakultas Kedokteran Universitas Sebelas Maret), yang menetapkan angka kelulusan minimal 70 (B) untuk setiap angkatan dari tahun 2014-2016 terdapat lebih dari 20\% mahasiswa yang harus mengikuti ujian ulang. Bahkan, di setiap semesternya dari 4 blok yang ada, lebih dari 50\% mahasiswa harus mengikuti ujian ulang pada 1 hingga 3 blok. ${ }^{5}$ Ujian blok adalah ujian untuk mengukur keberhasilan proses belajar mengajar mahasiswa yang dilaksanakan setelah kegiatan 2 blok selesai. Untuk masing-masing blok, ujian ulang hanya ditujukan kepada mahasiswa yang belum kompeten (nilai di bawah 70). Itu berarti setiap semester, untuk masing-masing ujian blok yang diujikan, sekitar 20-80\% mahasiswa mendapat nilai ujian blok di bawah 70.,6 Untuk mendapatkan nilai di atas 70, idealnya mahasiswa perlu menguasai 70\% materi terkait blok tersebut. Oleh karenanya, penting bagi mahasiswa untuk membaca dan mempelajari literatur terkait blok yang dihadapi.

Minat baca yang kurang disebabkan oleh pengetahuan awal mahasiswa yang tidak memadai, ketidakmampuan untuk memahami teks bacaan, dan struktur kompleks buku teks. ${ }^{2}$ Peningkatan minat baca terjadi jika kesempatan yang cukup diberikan untuk meningkatkan motivasi, dan hal lainnya yang juga ikut berperan seperti kepercayaan, kemampuan bahasa Inggris, dan pengetahuan di bidangnya. ${ }^{2}$ Oleh karena itu, diperlukan penelitian tentang pengaruh motivasi membaca literatur berbahasa Inggris terhadap nilai ujian blok mahasiswa Prodi Kedokteran FK UNS.

\section{METODE}

Jenis penelitian yang dilakukan di Fakultas Kedokteran UNS Surakarta pada bulan Januari 2018 ini adalah observasional analitik dengan pendekatan cross sectional. Populasi penelitian adalah seluruh mahasiswa aktif angkatan 2014, 2015, dan 2016 yang berjumlah 725 orang. Tingkat kesalahan yang 
dikehendaki adalah 5\%, maka dibutuhkan minimal 260 sampel. $^{7}$

Sampel penelitian dipilih dengan teknik sampling acak bertingkat, menggunakan pengocokan nomor. Dari 3 angkatan, masing-masing angkatan akan diambil sampel sesuai persentase jumlah angkatan.

Kriteria pembatas digunakan untuk mengendalikan variabel perancu. Kriteria inklusi yaitu, mahasiswa yang bersedia menjadi responden penelitian, dengan mengisi identitas diri dengan lengkap. Sedangkan kriteria eksklusi yaitu, mahasiswa yang berasal dari luar Indonesia, mahasiswa yang memiliki penyakit yang dapat mengganggu pembelajaran, dan mahasiswa yang merokok. Mahasiswa yang berasal dari luar Indonesia, memiliki bahasa ibu (bahasa sehari-hari) yang berbeda. Penyakit yang dapat mengganggu pembelajaran dapat mempengaruhi nilai mahasiswa. Berdasarkan literatur, merokok akan mempengaruhi kemampuan berpikir mahasiswa.
Data motivasi membaca literatur berbahasa Inggris diperoleh melalui pengisian Skala Motivasi Membaca Literatur Berbahasa Inggris (SMBI). Instrumen ini telah diuji reliabilitas pada penelitian sebelumnya, dengan nilai alfa Cronbach $0,93 .{ }^{\circ}$ Data nilai ratarata ujian blok (UB) dari 8 ujian blok pada tahun pertama diperoleh dari basis data Prodi Kedokteran FK UNS.

Data yang diperoleh kemudian diolah menggunakan program SPSS 22.0. Analisis data dilakukan secara univariat, secara bivariat dengan uji korelasi Spearman dan uji komparatif, dan secara multivariat dengan menggunakan uji regresi linear.

\section{HASIL DAN PEMBAHASAN}

Karakteristik responden dibagi menurut angkatan, usia, dan jenis kelamin, seperti yang dapat dilihat pada Tabel 1 .

Tabel 1. Karakteristik responden

\begin{tabular}{|c|c|c|c|c|c|}
\hline \multirow[b]{2}{*}{ No } & \multirow[b]{2}{*}{ Karakteristik } & \multirow{2}{*}{$\begin{array}{l}\text { Jumlah } \\
\text { (n) }\end{array}$} & \multirow{2}{*}{$\begin{array}{l}\text { Persen } \\
(\%)\end{array}$} & \multicolumn{2}{|c|}{ Mean \pm SD } \\
\hline & & & & SMBI & $\begin{array}{c}\text { Nilai Rata-Rata } \\
\text { UB }\end{array}$ \\
\hline 1 & Seluruh Responden & 274 & 100 & $151,66 \pm 22,99$ & $61,87 \pm 8,94$ \\
\hline \multirow[t]{10}{*}{2} & Angkatan & & & & \\
\hline & 2014 & 89 & 32,48 & $150,81 \pm 22,78$ & $65,32 \pm 7,17$ \\
\hline & Min & & & 100 & 47,91 \\
\hline & Maks & & & 210 & 80,41 \\
\hline & 2015 & 92 & 33,58 & $153,11 \pm 21,68$ & $61,48 \pm 7,67$ \\
\hline & Min & & & 116 & 32,42 \\
\hline & Maks & & & 201 & 77,31 \\
\hline & 2016 & 93 & 33,94 & $151,04 \pm 24,57$ & $58,46 \pm 10,13$ \\
\hline & Min & & & 63 & 20,00 \\
\hline & Maks & & & 209 & 77,34 \\
\hline \multirow[t]{7}{*}{3} & Usia & & & & \\
\hline & $<20$ tahun & 82 & 29,93 & $154,78 \pm 24,50$ & $59,39 \pm 9,86$ \\
\hline & Min & & & 63 & 20,00 \\
\hline & Maks & & & 207 & 77,34 \\
\hline & 20 tahun & 95 & 34,67 & $150,46 \pm 23,12$ & $61,34 \pm 8,49$ \\
\hline & Min & & & 111 & 36,88 \\
\hline & Maks & & & 210 & 77,41 \\
\hline
\end{tabular}




\begin{tabular}{|c|c|c|c|c|}
\hline$>20$ tahun & 97 & 35,40 & $150,20 \pm 21,47$ & $64,48 \pm 7,88$ \\
\hline Min & & & 100 & 32,42 \\
\hline Maks & & & 198 & 80,41 \\
\hline
\end{tabular}

$4 \quad$ Jenis kelamin

\begin{tabular}{|c|c|c|c|c|}
\hline Laki-laki & 83 & 30,29 & $154,31 \pm 23,89$ & $61,14 \pm 9,23$ \\
\hline Min & & & 113 & 36,88 \\
\hline Maks & & & 209 & 80,25 \\
\hline Perempuan & 191 & 69,71 & $150,51 \pm 22,55$ & $62,18 \pm 8,82$ \\
\hline Min & & & 63 & 20,00 \\
\hline Maks & & & 210 & 80,41 \\
\hline
\end{tabular}

Jumlah responden pada setiap angkatan cenderung sama. Distribusi responden berdasarkan usia, menempatkan responden yang berusia >20 tahun dengan jumlah terbanyak sebesar 35,40\%. Responden yang berjenis kelamin perempuan lebih banyak daripada laki-laki. Hal ini menggambarkan situasi yang sama pada populasi, yaitu mahasiswa Prodi Kedokteran FK UNS.

Skor rata-rata SMBI seluruh responden berada pada kategori sedang. Skor rata-rata SMBI pada kelompok angkatan 2015, usia di bawah 20 tahun, dan jenis kelamin laki-laki memiliki nilai yang lebih tinggi daripada kelompok variabel lainnya. Tetapi, skor SMBI tertinggi dimiliki oleh mahasiswa dari angkatan 2014.

Nilai rata-rata UB seluruh responden yaitu 61,87. Jika dikonversikan ke penilaian huruf, maka setara dengan C (cukup). Nilai rata-rata UB pada kelompok angkatan 2014, usia di atas 20 tahun, dan jenis kelamin perempuan memiliki nilai yang lebih tinggi daripada kelompok variabel lainnya.

Skor SMBI dibagi menjadi tiga kategori, yaitu rendah, sedang dan tinggi. Distribusi responden terbanyak berada pada kategori sedang, seperti yang terdapat pada tabel 2.

Tabel 2. Distribusi responden berdasarkan kategori skor SMBI

\begin{tabular}{cccc}
$\begin{array}{c}\text { Skor } \\
\text { SMBI }\end{array}$ & Kategori & $\begin{array}{c}\text { Frekuensi } \\
(\mathbf{n})\end{array}$ & $\begin{array}{c}\text { Persentase } \\
(\%)\end{array}$ \\
$44-102$ & Rendah & 3 & 1,10 \\
$103-161$ & Sedang & 181 & 66,10 \\
$162-220$ & Tinggi & 90 & 32,85 \\
\hline
\end{tabular}

Tabel 3. Distribusi responden berdasarkan kategori skor komponen SMBI

$\begin{array}{lcccc}\text { Skor Komponen SMBI } & \text { Kategori } & \text { Frekuensi (n) } & \text { Persen (\%) } & \text { Mean } \pm \text { SD } \\ \text { Motivasi Intrinsik } & & & & 58,46 \pm 11,10 \\ 18-42 & \text { Rendah } & 20 & 7,30 & \\ 43-66 & \text { Sedang } & 186 & 67,88 & \\ 67-90 & \text { Tinggi } & 68 & 24,82 & \\ \text { Motivasi Ekstrinsik } & & & & 20,70 \pm 3,28 \\ 6-14 & \text { Rendah } & 8 & 2,92 & \\ 15-22 & \text { Sedang } & 177 & 64,60 & \\ 23-30 & \text { Tinggi } & 89 & 32,48 & \end{array}$


Pentingnya membaca

10-23

$24-36$

$37-50$

Kemampuan membaca

10-23

24-36

$37-50$
Rendah

Sedang

Tinggi

Rendah

Sedang

Tinggi
$39,66 \pm 5,42$

0,37

25,18

74,45

$32,84 \pm 6,66$
Skor rata-rata komponen Motivasi Intrinsik, Motivasi Ekstrinsik, dan Kemampuan Membaca berada pada kategori sedang, seperti yang terdapat pada tabel 3 . Sedangkan komponen Pentingnya Membaca berada pada kategori tinggi. Hal ini sesuai penelitian yang membahas faktor-faktor dalam motivasi membaca. Seseorang mungkin tidak memiliki ketertarikan kepada membaca, mungkin juga menunjukkan sikap yang negatif terhadap membaca, tetapi, seseorang itu tetap bisa menyadari pentingnya membaca. ${ }^{9}$

Berdasarkan uji komparatif menggunakan One Way ANOVA untuk variabel angkatan dan usia, dan Uji T Tidak Berpasangan untuk variabel jenis kelamin, didapatkan hasil bahwa tidak ada perbedaan skor SMBI yang signifikan antar kelompok angkatan, usia, maupun jenis kelamin.

Hal ini sesuai dengan penelitian tentang perilaku mahasiswa yang menggunakan bahasa Inggris sebagai bahasa asing di Libia. Tidak didapatkan perbedaan yang signifikan antara tahun ajaran atau angkatan dan usia terhadap perilaku berbahasa Inggris. ${ }^{10}$ Perilaku ini termasuk ke dalam Motivasi Intrinsik, yang merupakan salah satu komponen SMBI. Beberapa penelitian lain menunjukkan bahwa tidak terdapat perbedaan kekuatan motivasi dan perilaku mahasiswa dalam literasi berbahasa Inggris berdasarkan jenis kelamin. ${ }^{11}$

Penelitian lain ada yang memberikan hasil bahwa terdapat perbedaan motivasi dalam belajar yang signifikan antara perempuan dan laki-laki dari berbagai angkatan Jurusan Kedokteran. Hasil penelitian tersebut menunjukkan bahwa perempuan memilki motivasi yang lebih baik daripada laki-laki. ${ }^{12}$ Hal ini juga terkait dengan usia, karena kematangan berpikir wanita lebih maju tiga tahun dari pada lakilaki sesusianya, pada usia sekitar 18 tahun. ${ }^{13}$

Pada penelitian ini, motivasi membaca literatur berbahasa Inggris yang relatif sama dapat terjadi karena mahasiswa berada di lingkungan yang sama, metode pembelajaran yang sama, kebiasaan belajar dan persiapan ujian yang cenderung sama dari tahun ke tahun.

Uji komparatif juga dilakukan pada nilai ratarata UB menggunakan uji Kruskal-Wallis, karena data nilai rata-rata UB tidak terdistribusi normal. Didapatkan hasil bahwa terdapat perbedaan nilai rata-rata UB yang signifikan antar semua kelompok angkatan, dan antara kelompok usia di atas 20 tahun dengan kelompok usia lainnya. Sedangkan jika berdasarkan jenis kelamin, hasil uji Mann-Whitney tidak menunjukkan adanya perbedaan nilai rata-rata ujian blok yang signifikan $(p=0,321)$.

Hasil ini sesuai dengan penelitian yang dilakukan terhadap 134 mahasiswa di universitas di Inggris. Penelitian tersebut menunjukkan bahwa usia merupakan salah satu faktor yang mempengaruhi performa akademik. Mahasiswa dengan usia yang lebih matang memiliki nilai akhir yang lebih tinggi daripada usia yang lebih muda dengan signifikasi $\mathrm{p}=0.01$ dan nilai $\mathrm{R}^{2}$ sebesar 0,05 , yang berarti perbedaan usia mempengaruhi nilai akhir sebesar 5\%. Usia yang lebih muda dikategorikan untuk kelompok usia di bawah 21 tahun. ${ }^{14}$

Hal ini mungkin disebabkan karena pada penelitian ini terdapat nilai salah satu responden yang berusia di bawah 20 tahun, yang tergolong outlier. Dapat pula dijelaskan karena mahasiswa yang berusia lebih tua melihat pendidikan sebagai katalisator 
perubahan dalam kehidupan mereka dan merasakan tekanan yang luar biasa untuk berhasil. Selain itu, tingkat kepercayaan yang lebih tinggi karena lebih berpengalaman juga berpengaruh terhadap keberhasilan belajar. ${ }^{15}$

Penelitian yang dilakukan pada 175 mahasiswa di Universitas Delta Stage di Abraka ini menunjukkan bahwa tidak terdapat perbedaan antara jenis kelamin laki-laki dan perempuan terhadap nilai akhir $(p=0,788) \cdot{ }^{16}$ Penjelasan yang memungkinkan adalah baik mahasiswa laki-laki maupun perempuan berada pada lingkungan sosial dan akademis yang sama, jadi reaksi mereka terhadap penilaian akademik serupa. $^{17,18}$ Berbeda dengan hasil penelitian di Jordan dan Saudi Arabia yang menunjukkan bahwa performa akademik perempuan lebih dominan. ${ }^{19,20}$ Penelitian lain menunjukkan dominansi laki-laki terhadap perempuan dalam performa akademik. ${ }^{21}$ Pada penelitian yang lain, ditemukan hasil performa akademik yang sama antara mahasiswa kedokteran laki-laki dengan perempuan pada penilaian melalui nilai akhir yang setara dengan Indeks Prestasi Kumulatif. Jika dilakukan penilaian melalui ujian klinik atau praktik yang setara dengan OSCE
(Objective Structured Clinical Examination) mahasiswa perempuan lebih unggul daripada mahasiswa lakilaki. Hal ini mencerminkan kemampuan perempuan yang lebih baik di bidang kerja sama, komunikasi dengan pasien, wawancara, dan konseling..$^{22}$

Uji korelasi bivariat dua arah antara SMBI dengan nilai rata-rata UB menggunakan uji korelasi Spearman, karena data nilai rata-rata UB tidak terdistribusi normal. Hasil menunjukkan bahwa terdapat hubungan $(\mathrm{p}=0,000)$ antara motivasi membaca literatur berbahasa Inggris dengan nilai rata-rata UB dengan kekuatan korelasi lemah $(\mathrm{r}=0,215)$.

Terdapat hubungan lemah $(\mathrm{r}=0,321)$ antara angkatan dengan nilai rata-rata UB $(p=0,000)$. Terdapat hubungan lemah $(0,221)$ antara usia dengan nilai ratarata UB $(\mathrm{p}=0,000)$. Uji korelasi Eta menunjukkan bahwa tidak terdapat hubungan yang bermakna antara jenis kelamin dengan nilai rata-rata UB $(\mathrm{p}=0,377)$. Tidak terdapat hubungan yang signifikan antara angkatan $(p=0,454)$, usia $(p=0,072)$, dan jenis kelamin $(p=0,209)$ dengan motivasi membaca literatur berbahasa Inggris.

Tabel 4. Regresi linear SMBI, angkatan, usia dengan nilai rata-rata ujian blok

\begin{tabular}{lccccc} 
& Koefisien Regresi & $\mathrm{p}$ & \multicolumn{2}{c}{$95 \%$ Confidence Interval } & R Square \\
Konstanta & 38,677 & 0,000 & & & 0,183 \\
SMBI & 0,104 & 0,000 & 0.061 & 0,146 & \\
Angkatan & 3,526 & 0,000 & 1,818 & 5,233 \\
Usia & 0,236 & 0,789 & $-1,495$ & 1,967 \\
p Regresi & & 0,000 & & \\
\hline
\end{tabular}

Variabel Dependen: Nilai Rata-Rata Ujian Blok

Hasil uji regresi linear pada tabel 4 menunjukkan bahwa motivasi membaca literatur berbahasa Inggris, angkatan dan usia secara simultan mempengaruhi nilai rata-rata UB. Hasil ini sesuai dengan penelitian lain. ${ }^{14,23}$ Hasil uji regresi linear ini menghasilkan persamaan sebagai berikut $U B=38,677+0,104$ $(\mathrm{SMBI})+3,526($ Angkatan$)+0,236$ (Usia).
Berdasarkan persamaan tersebut didapatkan bahwa motivasi membaca literatur berbahasa Inggris memiliki korelasi positif yang bermakna dengan nilai rata-rata ujian blok, setiap peningkatan satu skor SMBI maka terdapat peningkatan nilai ratarata ujian blok sebesar 0,104. Penelitian pada 273 mahasiswa Jurusan Keperawatan menunjukkan hasil yang sama dengan penelitian ini, terdapat korelasi 
positif antara kemampuan dalam literasi berbahasa Inggris dengan performa akademik. ${ }^{24}$

Hasil penelitian ini bertolak belakang dengan penelitian yang dilakukan pada mahasiswa kedokteran, Universiti Sains Islam Malaysia. Hasil pada penelitian tersebut menunjukkan bahwa tidak ada korelasi yang signifikan antara literasi berbahasa Inggris dengan performa akademik, dengan $\mathrm{p}=0,886 .{ }^{25}$

Perbedaan hasil ini mungkin terjadi karena terdapat perbedaan dalam mengukur performa akademik. Pada penelitian yang dilakukan di Malaysia tersebut performa akademik hanya diukur melalui nilai satu mata kuliah Patologi yang diujikan pada semester $6 .{ }^{25} \mathrm{Hal}$ ini berbeda dengan penelitian ini yang menilai seluruh mata kuliah yang telah diterima mahasiswa pada tahun pertama menggunakan nilai rata-rata ujian blok. Nilai rata-rata ujian blok ini menggambarkan performa akademik mahasiswa dalam kurun waktu yang panjang (1 tahun).

Nilai $\mathrm{R}$ square pada tabel 4 menunjukkan bahwa motivasi membaca literatur berbahasa Inggris, angkatan, dan usia berpengaruh secara simultan terhadap nilai rata-rata ujian blok sebesar $18,3 \%$. Persentase yang tidak mencapai $100 \%$ ini menggambarkan bahwa terdapat faktor lain yang mempengaruhi nilai rata-rata ujian blok yang tidak dapat dijelaskan pada penelitian ini.

Faktor yang mempengaruhi performa akademik atau hasil ujian dijelaskan dalam penelitian lain yang dilakukan terhadap 1668 mahasiswa baru, tingkat dua, tingkat tiga, dan tingkat akhir di universitas di Turki. Faktor tersebut diantaranya, kemampuan manajemen waktu antara kepentingan akademik dan sosial, kemampuan belajar dan kebiasaan baik saat belajar di dalam kelas. ${ }^{26}$

Faktor lain dijelaskan dalam penelitian yang dilakukan pada mahasiswa kedokteran di UniSZA, Malaysia. Diantaranya, 1) motivasi menjadi mahasiswa kedokteran; 2) bahan utama yang digunakan dalam menghadapi ujian; 3) waktu yang digunakan dalam bermedia sosial yang tidak berhubungan dengan mata kuliah; 4) waktu yang digunakan untuk persiapan ujian. ${ }^{27}$
Keterbatasan penelitian ini adalah faktor yang mempengaruhi nilai rata-rata ujian blok tidak diteliti seluruhnya, antara lain kemampuan awal mahasiswa yang mungkin berbeda, karakter blok yang berbeda-beda, strategi belajar mahasiswa, dan lain-lain. Desain penelitian menggunakan cross sectional, sehingga mekanisme hubungan sebab akibat lebih lemah dibandingkan rancangan yang lain. Kekuatan penelitian ini adalah penelitian ini sudah mempertimbangkan pengaruh usia, jenis kelamin, dan angkatan masuk mahasiswa, serta ukuran sampel yang cukup besar.

\section{KESIMPULAN}

Ada pengaruh motivasi membaca literatur berbahasa Inggris terhadap nilai rata-rata ujian blok mahasiswa Prodi Kedokteran FK UNS, dengan mempertimbangkan angkatan dan usia.

\section{SARAN}

Mahasiswa perlu meningkatkan motivasi membaca literatur berbahasa Inggris, misalnya dengan cara meningkatkan kemampuan berbahasa Inggris. Perlu dilakukan penelitian lebih lanjut dengan mempertimbangkan faktor kebiasaan mahasiswa dalam belajar, seperti belajar dengan latihan soal. Institusi pendidikan kedokteran perlu memfasilitasi mahasiswa untuk meningkatkan motivasi membaca literatur berbahasa Inggris, misalnya dengan membiasakan memberi referensi atau bacaan berbahasa Inggris.

\section{DEKLARASI KEPENTINGAN}

Para penulis mendeklarasikan bahwa tidak terdapat konflik kepentingan apapun terkait studi pada naskah ini.

\section{KONTRIBUSI PENULIS}

Dinda Carissa - menyusun tinjauan pustaka, hasil penelitian, pembahasan, dan naskah publikasi

Yunia Hastami - menyusun kuesioner SMBI, meninjau ulang tinjauan pustaka dan naskah publikasi 
Eti Poncorini Pamungkasari - menyusun rancangan penelitian, meninjau ulang hasil penelitian dan pembahasan.

\section{DAFTAR PUSTAKA}

1. Baswedan A. Gawat darurat pendidikan di Indonesia [document on the internet]. Kementrian Pendidikan; 2014 [cited 2017 Sep 30]. Available from: https://pendidikan. kulonprogokab.go.id/files/Paparan $\% 20$ Materi\%20Pendidikan\%20di\%20Indonesia. pdf

2. Masqudi H. EFL reading in Indonesian universities: perspectives and challenges in cultural contexts. Journal of Teaching and Education. 2014;03(3): 385-97.

3. Juni P, Holenstein F, Sterne J, Bartlett C, Egger M. Direction and impact of language bias in meta-analyses of controlled trials: empiric study. International Journal of Epidemiology. 2002;31:115-23.

4. Mattarima K, Hamdan AR. The teaching constraints of English as a foreign language in Indonesia: the context of school based curriculum. Sosiohumanika. 2011;4(2):287-300.

5. Prodi Kedokteran FK UNS. Pengumuman ujian remidiasi [document on the internet]. Fakultas Kedokteran UNS; 2016 [cited 2017 Sep 30]. Available from: http://prodikedokteran.fk.uns. ac.id/

6. Akademik FK UNS. Buku pedoman Program Studi Kedokteran-Fakultas Kedokteran UNS. Surakarta: Fakultas Kedokteran UNS; 2016.

7. Cohen L, Manion L, Morrison K. Research methods in education. $6^{\text {th }} \mathrm{ed}$. Oxon: Routledge; 2007.

8. Mori S. Redefining motivation to read in a foreign languange. Reading in a Foreign Language. 2002;14(2); 91-110.

9. Jang BG, Conradi K, McKenna MC, Jones JS. Motivation: approaching an elusive concept through the factors that shape it. The Reading Teacher. 2015;69(2): 239-47.
10. Abidin MJZ, Pour-Mohammadi M, Alzwari H. EFL students' attitudes toward learning english language: the case of Libyan secondary school students. Asian Social Science. 2012;8:119-34.

11. Fakeye D. Students' personal variables as correlates of academic achievement in English as second language in Nigeria. Journal pf Social Sciences. 2010;22:205-11.

12. Kusurkar R, Kruitwagen C, Cate O, Croiset G. Effect of age, gender and educational background on strength of motivation for medical school. Springer Nature. 2010;15(3): 303-13.

13. Westenberg PM. De Jeugd van Tegenwoordig [document on the internet]. Leiden University; 2008 [cited 2018 Feb 1]. Available from: http:// www.leidenuniv.nl/tekstboekjes/content docs/ oratie westenberg.pdf

14. Sheard M. Hardiness commitment, gender, and age differentiate university academic performance. The British Psychological Society. 2009;79:189-204.

15. Shanahan M. Being that bit older: Mature students' experience of university and healthcare education. Occupational Therapy International. 2006;7:153-62.

16. Okoh EEE. Influence of age, finacial status, and gender on academic performance among undergraduates. Journal of Psychology. 2017;1(2): 99-103.

17. Ugoji FN. The impact of counselling on the academic performance of secondary school student. Africa Journal for Inter Disciplinary Studies. 2008;8(2):67-73.

18. Faisal R, Shinwari L, Hussain SS. Academic performance of male in comparison with female undergraduate medical student in Pharmacology examinations. J Pak Med Assoc. 2017;67(2):2048.

19. Khwaileh FM, Zaza HI. Gender differences in academic performance among undergraduates at the University of Jordan: are they real or stereotyping. Coll Stud. 2011;45:722-35.

20. Deepak KK, Al-Umran KU, Al-Sheikh MH, Al-Rubaish A. The influence of gender on 
undergraduate performance in multiple choice testing in clinical disciplines at University of Dammam, Saudi Arabia. J Med Sci. 2011;4:12330.

21. Josiah O, Adejoke EO. Effect of gender, age, and mathematics anxiety on college students' achievement in Algebra. Am J Educ Res. 2014;2:474-6.

22. Dixon D. Gender differences in academic qualifications and medical school performance of osteopathic medical student. IAMSE. 2007;17(1):33-7.

23. Ogenler O, Selvi H. Variables affecting medical faculty students' achievement: a mensin university sample. Iran Red Cresent Medical Journal. 2014;16(3).

24. Salamonson Y. English-language acculturation predicts academic performance in nursing student who speak English as a second language.
Research in Nursing and Health. 2008;31(1): 8694.

25. Sanip S dan Zulkifli NF. Significance of English literacy and academic performance of medical students in USIM. Journal for Educational Studies. 2011;4(1):93-8.

26. Erdem HE. A cross sectional survey in progress on factors affecting students' academic performance at Turkish university. ProcediaSocial and Behavioral Sciences. 2013;70:691-5.

27. Haque M, Rahman NAA, Majumder AA, Rahman NIA, Haque SZ, Zulkifli Z, Lugova H et al.. Assessment of academic/non-academic factors and extracurricular activities influencing performance of medical students of Faculty of Medicine, Universiti Sultan Zainal Abidin, Malaysia. Advances in Human Biology. 2018;8(1):4-18. 